\title{
ARTIGO
}

CO https://doi.org/10.22481/praxisedu.v15i36.5890

\section{STUDENT SOCIO-PSYCHOLOGICAL EXPECTATIONS FROM STUDYING IN HIGHER EDUCATION INSTITUTION: SATISFACTION DEGREE AND IMPLEMENTATION EVALUATION}

\author{
EXPECTATIVAS SOCIOPSICOLÓGICAS DE LOS ESTUDIANTES AL ESTUDIAR EN \\ UNA INSTITUCIÓN DE EDUCACIÓN SUPERIOR: GRADO DE SATISFACCIÓN Y \\ EVALUACIÓN DE IMPLEMENTACIÓN
}

EXPECTATIVAS SÓCIO-PSICOLÓGICAS DOS ESTUDANTES EM INSTITUIÇÕES DE ENSINO SUPERIOR: GRAU DE SATISFAÇÃO E AVALIAÇÃO DA IMPLEMENTAÇÃO

Rimma R. Khanmurzina Kazan Innovative University named after V. G. Timiryasov, Kazan - Russia

Denis G. Shelevoi Pacific State University, Khabarovsk - Russia

Larisa I. Tararina Russian State Social University, Moscow - Russia

Elena Yu. Mazhuga Jewish University, Moscow - Russia

Maxim S. Fabrikov Vladimir State University named after Alexander Grigorievich and Nikolai Grigorievich Stoletov, Vladimir - Russia

Larisa A. Kosolapova Perm State University, Perm - Russia

Anna I. Skorobogatova Kazan Innovative University named after V. G. Timiryasov, Kazan - Russia

Maria A. Matveeva Russian Transport University (RUT MIIT), Moscow - Russia

Abstract: The aim of the study is to analyze the implementation of students' expectations from studying at the University. The leading method for the study of this problem is the method of the questionnaire, which allows the most qualitative and in-depth study of the 
expectations of young people in relation to higher education.. It is revealed that the existing problems have a negative impact on the attitude of students to their educational institution and, consequently, reduce its image in the eyes of future students and the public as a whole. The data obtained in this work can be used in the psychology of education, age psychology, social psychology, pedagogy, sociology, as well as for further theoretical development of this issue.

Keywords: student youth, educational activities, expectations.

Resumen: El objetivo del estudio es analizar la implementación de las expectativas de los estudiantes al estudiar en la Universidad. El método principal para el estudio de este problema es el método del cuestionario, que permite el estudio más cualitativo y profundo de las expectativas de los jóvenes en relación con la educación superior. Se revela que los problemas existentes tienen un impacto negativo. sobre la actitud de los estudiantes hacia su institución educativa y, en consecuencia, reducir su imagen ante los futuros estudiantes y el público en general. Los datos obtenidos en este trabajo pueden utilizarse en psicología de la educación, psicología de la edad, psicología social, pedagogía, sociología, así como para un mayor desarrollo teórico de este tema.

Palabras clave: juventud estudiantil, actividades educativas, expectativas.

Resumo: O objetivo do estudo é analisar a implementação das expectativas dos alunos de estudar na Universidade. O método principal para o estudo desse problema é o método do questionário, que permite o estudo mais qualitativo e aprofundado das expectativas dos jovens em relação ao ensino superior. É revelado que os problemas existentes têm um impacto negativo na atitude dos alunos em relação à sua instituição educacional e, consequentemente, reduzir sua imagem aos olhos dos futuros alunos e do público em geral. Os dados obtidos neste trabalho podem ser utilizados nas áreas de psicologia da educação, psicologia da idade, psicologia social, pedagogia, sociologia, bem como para o desenvolvimento teórico adicional desta questão.

Palavras-chave: jovens estudantes, atividades educativas, expectativas

\section{Introduction}

Currently, in the context of reforming the system of higher education and transition to new educational standards, it is important to know the attitude of the subjects of the educational process to the changes. The opinion of the students themselves is particularly significant, as it is largely an indicator of how the higher education system meets their expectations. When an applicant chooses which higher education institution he will receive a future specialty, he forms certain expectations for this institution. Moreover, if expectations 
are not met, it negatively affects the image of the University, reduces its rating and attractiveness in the eyes of potential students and the public as a whole. An important stage in the life of a young person is the process of his entry into society through socialization, that is, the assimilation of the norms and rules characteristic of this society. One of the institutions that ensure the adaptation of young people to their social environment is the Institute of education (Alisov \& Cherdymova, 2018; Sorokoumova et al., 2019; Kalugina, 2013; Zotova, 2017; Prakhov, 2017). Education has been essential in every culture throughout human history. Education in itself, as a value, is of great importance in the minds of modern students, but in comparison with other values, often of an individual nature, concerning the young person and his personal life, is not quite popular. Each applicant, entering a higher education institution, assesses the prospects for higher education and their plans after University (Boyak, 2014; Verevkin, 2010; Cherdymova et al., 2018; Cherdymova et al., 2019; Suprunenko, 2015). Regarding admission, the quality of education, University life in General, potential future students form their expectations. Conducting research on expectations is a promising area that helps to understand what an individual or a community wants. Youth expectations in the student sphere especially need to be studied, as young people - the most mobile socio-demographic group, is the successor of traditions, which also carries the beginnings of a new culture, young people adapt to the existing system, but also adapt new patterns of behavior to themselves. Student youth is on the periphery between schooling that was recently, life in the parental home and exit into adulthood, when the young man himself will decide what to do. Some students begin to work from the first year of University and, therefore, they form an idea of the importance of their own resources, so for them the expectations of the education will be higher, because they understand that they spend time, effort and money on it. Carrying out such studies, the analysis of the results can allow to create the most effective and conscious transition between such basic points as schoolUniversity-work, when a young person will be confident in his choice, when he will understand that the education he receives will really give him the opportunity to settle in life and take the expected social position.

\section{Literature Review}

In modern science, the term expectation is used in various disciplines and each of them has its own characteristics in the definition. In addition, for example, two terms are used 
in sociology - expectations and social expectations (Chernoivanenko \& Valiakhmetova, 2015; Nechaev, 2015a,b; Popovich, 2014; Gurina, 2007). Expectations, first, are individual in nature and relate to the image of the future result, which can be changed, approximated in time or distant through the activities of the subject of expectation. In sociology, the term expectation is most often mentioned in the framework of the theory of structural functionalism, as a set of individual expectations of a person due to his characteristic type of social behavior, his social status, as well as the characteristics of contemporary society (Gritsanov, 2003). With the accumulation of scientific knowledge, our understanding of the reality around us grows, one way or another, any phenomenon is subjected to study and acquires new theoretical approaches, expectation is no exception. The theory of adaptive expectations considers that the person estimates the future situation and expects any concrete changes, considering mistakes of the past and only on them is based. The theory of rational expectations assumes that a person makes his estimates about the future based on a set of variables: what mistakes were made in the past, what mistakes can be made in the future, what future is ahead (Koichueva \& Bogatyrev, 2014). Under the expectation of the subjects is understood probabilistic assessment of their ability and ability to carry out any action (Nechaev, 2015a,b). The study of expectations is not limited to theories of motivation. Expectations can also be studied as social expectations-subjective orientations in the form of a set of social attitudes, behavioral stereotypes, assessments that are shared by members of a social group or the whole society about the course of significant events that provide cognitive, emotional and behavioral readiness of individuals to these events (Gribov, 2016). The subjective expectations of the individual concern at least two aspects of the future: the individual and the social. Individual expectations are ideas about the future, associated with their own lives and their loved ones. The social expectations of a particular person may take the form of vague ideas, vague fears, hopes or coherent theories of social reconstruction, political programs, and literary utopias (Zheltikova, 2014). Students' expectations of studying at the University are images of studying at the University considering by them as the most probable in a situation of uncertainty. Education is a hot topic of discussion today, especially given that various researchers believe that the Russian education system is in a state of crisis. The crisis here means that although education itself has a certain level of competitiveness, it is quite difficult to apply education for practical purposes because of the state of the Russian economy, which requires a lot, but provides little (Kasyanov, Lyubetsky \& Samygin, 2017). The advantages and disadvantages of the current education system, its future prospects, what needs to be 
changed, improved and what needs to be preserved are actively discussed. Also important is the fact that it is impossible to consider the institution of education without affecting its functions, among which are: socialization, education, and creation of a competitive base of employees, both for the internal and external market, which is understood as the exchange of valuable personnel and international cooperation, and all those who are actively involved in this system. First, these are people receiving higher education, as well as employees of higher educational institutions. Many studies confirm the fact that the system of values of modern students differs by great pragmatism from the values of the youth who lived in the period of existence of Russia before perestroika. The General direction of reforms of economic and social life in our country has significantly changed not only the situation in the system of life values of modern youth, but also made some adjustments to its attitudes to higher education and the hierarchy of motives for choosing a future profession (Koltunova \& Molotkova, 2014). At the present stage of globalization, the transition to a new knowledge-based economy has been clearly defined. Fundamentally new in the new economy is the loss of the dominant role of financial capital in wealth creation. Intellectual and social capital began to play a decisive role (Mayer \& Vlasyuk, 2012). The accumulation of knowledge, its application in the professional environment is directly related to the education system. The quality of education itself determines how successful and competitive consumers of higher education services will be. At present, not only Russian, but also the world education as a whole has entered the era of fundamental changes, which are directly related to the evolutionary changes in society (Ursul \& Ursul, 2014). It is important to understand that the modern global trend is the customization of all aspects of human life (Vapnyarskaya, 2014). Customization refers to the creation of a product based on the individual preferences of the customer. This is fully typical for the economy, when a person has the opportunity to create a unique product design. The same trend will accompany the sphere of education; it will become more and more individualized. Lectures in the University building, physical presence and binding to the place will become outdated. The student will have the opportunity to choose the courses, teachers, skills that he wants to master, the student will choose the educational curriculum, and teachers in this case will act as a source of information. In addition, here expectations will take a dominant place, as their satisfaction will be the basis for the success of the educational segment. It is necessary to understand that higher education is still a certain product, so for its continuous improvement it is necessary to study the opinion of its main consumers. This may be research aimed at studying students' satisfaction with the 
process of learning in higher education institution, the quality of services provided to students, as well as the implementation of students' expectations that they had before entering higher education institution.

\section{The Purpose and Structure of the Pilot Study}

The questionnaire aimed at studying students' expectations from studying at the University consisted of several parts. The first set of questions was devoted to educational activities and included questions about the implementation of expectations from lectures, from the content of the taught material and its presentation by teachers. The second part contained information about the respondents' expectations regarding the communication process at the University at all its levels: in the group, between the student and the teacher, as well as between the student and the administrative apparatus of the University. The third part reflects the expectations of students from the practice at the University. It is presented with a question as to how they assess University practice. The fourth set of questions reflects the range of respondents' expectations regarding leisure activity, namely sports and creative. The fifth set of questions related to scientific activities at the University and included questions about the implementation of expectations from participation in conferences, round tables and the like, awareness of scientific events and their organization. The pilot study addressed the following issues:

- What were the students' expectations regarding academic activities at the University?

- What were the students' expectations regarding research activities at the University?

- What were the students' expectations regarding creative activity at the University?

- What were the students' expectations regarding the organization of practical activities at the University?

- What were the students' expectations regarding sports activities at the University?

- What were the students' expectations regarding communication practices at the University?

- What factors influenced the choice of the applicant?

- What were the motives of the current student to enter a higher education institution? 
According to the results of the questionnaire, students' expectations of studying at the University in five areas were formulated: educational activities, scientific activities, practical activities at the University, leisure activities (creative and sports), as well as communication components at all levels.

\section{Result and Discussion}

The first task of the study was to determine the motives of students when entering the University. The vast majority of answers (68\%) are answers about obtaining knowledge and mastering the skills of the future profession. However, there were other options: parents insisted (5\%), entered the institute by points (18\%), and did not enter anywhere else (3\%). In quantitative representation, the majority of students on the question of how he learned about the University said that they received information about this institution from relatives or friends studying or having studied there (53\%), as well as directly from the Internet (43\%), which can tell us about the effectiveness of these sources of information. Open days are significantly inferior as a means of informing students. According to the results, students of Humanities and technical areas mainly chose a high level of expectations from lectures, but also noted the low degree of its implementation, which cannot be said about the low level of expectations, which, although not so many people chose, nevertheless, was more realized. Students of both directions also in the majority noted high level of expectations from presentation of material by the teacher, but at the same time also specified rather not high degree of realization of expectations $(51 \%)$. Those who thought that the teacher would communicate with them, and not just give a lecture, had a higher level of realization of expectations. The majority of respondents on all questions highlighted a high level of expectations, and on average students of both directions have the same level of realization of expectations. The majority of respondents noted the average level of expectations from their participation in various scientific events. According to the data obtained, the percentage of students willing to actively participate in various scientific activities in the Humanities is two times lower $(8 \%)$, which may indicate a greater desire of technical students to participate in such activities (18\%). In addition, it is interesting, that a large percentage of humanitarian respondents noted the low implementation of expectations from the number of conferences. Students of technical direction largely (42\%) felt that it would be easier to find people of interest to organize their own Association, while the degree of realization of expectations was 
relatively high. Most of the students noted a high level of expectations from the equipment of sports sections, although not every fourth Respondent (27\%) expected modern equipment of sports grounds. An interesting fact is that the most popular among students were high and medium levels of expectations from communication with the administrative apparatus of the University. At the same time, if the degree of implementation of the high level has equal proportions, the average level of the two directions was realized a little differently. Thus, students of the Humanities noted a greater degree of realization of the expectations of the average level. However, the expectations of those who had them at a low level were met largely. The majority of students noted a high level of expectations, but the degree of its realization was lower for students of the Humanities. More than half of students of technical specialties $(61 \%)$ would like to work only in the profession, while more than half of students of Humanities (68\%) were focused to other fields of activity. At the same time, the corresponding expectations were realized more among the Humanities.

\section{Conclusions}

The process of realization of students' expectations is quite complex and multifaceted. Various aspects that should not be overlooked either influence it. For example, the transition from school to higher education institution may affect the realization of expectations from studying at the University. An important place in the formation of expectations is the study of students' satisfaction with the quality of education. A special place is occupied by research on professional expectations of students. A student entering the University hopes to gain not only knowledge, but also skills that will be useful to him for further employment. Employers and University management are also interested in conducting such research in addition to the student himself, as employers will understand what generation of students is graduating from higher education institutions; what approach should be taken to them and what they expect from their profession. University needs in conducting such research to monitor its own level of education, as well as to monitor the cooperation with leading enterprises that need new staff. Analysis of the results shows that the highest salary is expected to receive by students of such specialties as Information technology, Economics and management, and the lowest — students of specialties Pedagogy and cultural Studies. The expected return on education is the highest for students of technical, mathematical and natural Sciences, and the lowest return on education is expected to be received, as in the case of 
expected wages, by students of pedagogical specialties. Nevertheless, they predict a very high value of higher education in relative terms, that is, they believe that without studying at the University they will be able to earn much less. Based on the results, it can be concluded that many students draw a parallel between higher education and high wages. The modern education system has largely become public. This can be determined by the sufficient prevalence of people with higher education in different countries. Whereas in the past the education system was considered to be a component of status, that is, only members of the upper strata of society could apply for education in special institutions, now it is a fairly widespread and accessible institution that affects many socio-demographic groups. This position defines it as one of the types of social elevators that allow you to take a higher place in the social and professional hierarchies. It is important to understand that the future is the improvement of the educational system. It is necessary to instill in the present and future generations not only purely pragmatic values, to transfer knowledge and skills, but also to form a holistic picture of the surrounding material and spiritual worlds in young people, to promote awareness of the belonging of each person to a single human community, to transmit from generation to generation cultural values in their universal understanding.

\section{REFERENCES}

1. Alisov, E. \& Cherdymova, E. (2018). and other Study of Dominant Type of Student Ecological Focus. Ekoloji, 27(106), 357-362.

2. Boyak, T.N. (2014). Education in the values of modern Russian youth. Scientific notes of TRANS-Baikal state University, 4, $14-20$.

3. Cherdymova, E.I., Afanasjeva, S.A., Parkhomenko, A.G., Ponyavina, M.B., Yulova, E.S., Nesmeianova, I.A. \& Skutelnik, O.A. (2018). Student ecological consciousness as determining component of ecological-oriented activity. EurAsian Journal of BioSciences Eurasia J Biosci, 12, 167-174

4. Cherdymova, E.I., Faleeva, L.V., Ilkevich, N.G., Sharonov, I.A., Sayfutdinova, G.B., Leusenko, I.V. \& Popova, O.V. (2019). Socio-Psychological Factors that Contribute to and Impede the Process of Student Eco-Vocational Consciousness Formation. Ekoloji, 28(107), 133-140

5. Chernoivanenko, Yu.O. \& Valiakhmetova, M.M. (2015). Social expectations and hope. Social phenomena, 3, 41-45.

6. Gribov, D.E. (2016). Social expectations as a regulator of social behavior of a person: theoretical problems of research. Humanitarian of the South of Russia, 6, 182-189.

7. Gritsanov, A.A. (2003). Sociology: Encyclopedia. Minsk: Publishing Book House. 
8. Gurina R. V. (2007) Implementation of students' expectations as an indicator of learning effectiveness. Psychological science and education, 4, 7-15.

9. Kalugina, D.A. (2013). Quality of content, process and result of education through the eyes of students: results of sociological research. Education and science, 6, 74-89.

10. Kasyanov, V.V., Lyubetsky, N.P. \& Samygin, S.I. (2017). The Crisis of higher education in Russia as a socio-cultural catastrophe. Humanities, socio-economic and social Sciences, 8, 18-27.

11. Koichueva, M.T. \& Bogatyrev, M.M. (2014). Inflation expectations and methods of their study. Scientific journal of national research University of information technologies, mechanics and optics, 4, 41-49.

12. Koltunova, Yu.I. \& Molotkova, T.L. (2014). Features of professional selfdetermination of modern Russian youth. Bulletin of Surgut state pedagogical University, 2, 184-188.

13. Mayer, B.O. \& Vlasyuk, N.N. (2012). Axiological aspects of education as a factor of sustainable development of society. Bulletin of Novosibirsk state pedagogical University, 4, 26-33.

14. Nechaev, A.V. (2015a). Social and philosophical aspects of expectations research. Social phenomenon, 3, 10-21.

15. Nechaev, I.A. (2015b). Influence of social expectations on the motivation of the subject in the expectation-value model. Social phenomenon, 3, 46-52.

16. Popovich, I.S. (2014). Social expectations in theories of personality motivation. Bulletin of the Perm University, 4, 53-63.

17. Prakhov, I.A. (2017). Determinants of expected returns from higher education. The issue of education, 1, 25-57.

18. Sorokoumova, E.A., Cherdymova, E.I., Rezvantseva, M.O., Kochneva, L.V., Latysheva, V.V. \& Perkova, E.P. (2019). Environmental and Social Practices of Old Stuff Use and Disposal by Students. Ekoloji, 28(107), 5065-5069.

19. Suprunenko, G.A. (2015). Higher education as a value of modern youth. Collection of conferences research and information center Sociosphere, 46, 158-160.

20. Ursul, A.D. \& Ursul, T.A. (2014). Megatrends of education evolution of the third Millennium. "Future Human Image", 3, 39-95.

21. Vapnyarskaya, O.I. (2014). Genesis and modern approaches to the definition of customization. Service in Russia and abroad, 6, 34-46.

22. Verevkin, O.L. (2010). The Value of education in the public consciousness. Public opinion monitoring, 4, 179-190.

23. Zheltikova, I.V. (2014). The Place of social expectations in the image of the future. Modern studies of social problems, 4, 235-246.

24. Zotova, V.A. (2017). International experience of student participation in education quality assessment. Journal of creative economy, 3, 303-314. 


\section{SOBRE OS AUTORES:}

\section{Rimma R. Khanmurzina}

$\mathrm{PhD}$ in Education, Associate Professor of the Department of Pedagogical Psychology and Pedagogics, Kazan Innovative University named after V. G. Timiryasov, Kazan, Russia. Email: rimmulya_19@mail.ru

iD http://orcid.org/0000-0001-5912-8349

\section{Denis G. Shelevoi}

$\mathrm{PhD}$ in Economics, Associate Professor of the Department of Economics and Management in Construction, Pacific State University, Khabarovsk, Russia. E-mail: dshel@yandex.ru

iD http://orcid.org/0000-0003-0568-3261

\section{Larisa I. Tararina}

$\mathrm{PhD}$ in Education, Associate Professor of the Department of Linguistics and Translation, Russian State Social University, Moscow, Russia. E-mail: 1t31@ mail.ru

iD http://orcid.org/0000-0002-0280-135X

\section{Elena Yu. Mazhuga}

$\mathrm{PhD}$ in Law, Associate Professor, Head of the Department of Legal Disciplines, Jewish University, Moscow, Russia. E-mail: elenamazhuga@yandex.ru

(iD http://orcid.org/0000-0001-8506-1352

\section{Maxim S. Fabrikov}

$\mathrm{PhD}$ in Education, Vice-Rector for Administrative Work and Management of Economic Complex, Vladimir State University named after Alexander Grigorievich and Nikolai Grigorievich Stoletov, Vladimir, Russia. E-mail: fabrikov33@mail.ru

iD http://orcid.org/0000-0001-5390-129X

\section{Larisa A. Kosolapova}

$\mathrm{PhD}$ in Education, Professor, Head of the Department of Pedagogy, Perm State University, Perm, Russia. E-mail: la_kossolapova@1st.ru

(iD http://orcid.org/0000-0002-5677-5417

\section{Anna I. Skorobogatova}

$\mathrm{PhD}$ in Education, Associate Professor, Head of the Department of Pedagogical Psychology and Pedagogics, Kazan Innovative University named after V. G. Timiryasov, Kazan, Russia. E-mail: a.i.skorobogatova@mail.ru

(iD http://orcid.org/0000-0003-1793-8161

\section{Maria A. Matveeva}

$\mathrm{PhD}$ in Law, Associate Professor of the Department of Transport Law, Russian Transport University (RUT MIIT), Moscow, Russia. E-mail: matveeva1987@mail.ru

(iD http://orcid.org/0000-0002-5184-8402 